\title{
Comparison of Effects of the Hypoglycemia Management Protocol with 40\% Dextrose Concentrated Solution to the Post-correction Blood Sugar Response through Intravenous Infusion and Intravenous Bolus
}

\author{
Yuriani $^{1}$, Retnosari Andarajati ${ }^{1}$, Laurentius A. Pramono ${ }^{2}$ \\ ${ }^{1}$ Faculty of Pharmacy, University of Indonesia, Depok, Indonesia \\ ${ }^{2}$ Department of Internal Medicine, Atma Jaya Hospital, Jakarta, Indonesia
}

\begin{abstract}
Hypoglycemic patients who receive $40 \%$ dextrose (D40\%) concentrated solution in the correction process need to avoid excessive blood glucose spikes. Administration of D40\% was found in two different ways, through intravenous infusion (iv infusion) and intravenous bolus (iv bolus) and the effects of both types of administration were unknown. The purpose of this study was to compare the effect of a hypoglycemia treatment protocol using $\mathrm{D} 40 \%$ concentrated solution to the post-correction blood sugar response through iv infusion and iv bolus at two different hospitals with two distinct protocols. This comparative analytical cross-sectional study was conducted retrospectively at St. Carolus Hospital (D40\% iv infusion group) and Bella Hospital (D40\% iv bolus group). Blood glucose responses, in form of coefficient of variation and degree of overcorrection, were compared between groups. The overall median blood glucose response was $69.5(3-195) \mathrm{mg} / \mathrm{dL}$ for iv infusion group $(\mathrm{n}=60)$ and $77(15-249)$ $\mathrm{mg} / \mathrm{dL}$ for iv bolus group $(\mathrm{n}=62)(\mathrm{p}=0.259)$. The coefficient of variation with iv infusion and iv bolus group were $47.18 \%$ and $52.75 \%$, respectively. The median of degree of overcorrection in iv infusion group was lower compared with iv bolus group, $10 \%(0-138 \%)$ versus $23 \%(0-195 \%)$, respectively. Both D40\% protocols did not have a significant correlation with the degree of overcorrection (MannWhitney test; $\mathrm{p}=0.099$ ). D $40 \%$ iv infusion and bolus administration had no effect to the post-correction blood sugar response.
\end{abstract}

Keywords: Blood glucose, dextrose $40 \%$, hypoglycemia, intravenous bolus, intravenous infusion

\section{Perbandingan Efek Protokol Manajemen Hipoglikemia dengan Larutan Pekat Dekstrosa 40\% secara Intravena Infus dan Intravena Bolus terhadap Respon Gula Darah Pascakoreksi}

\begin{abstract}
Abstrak
Pasien hipoglikemia yang menerima larutan pekat dekstrosa 40\% (D40\%) dalam proses koreksinya perlu menghindari lonjakan gula darah yang berlebih. Cara pemberian D40\% diberikan dengan dua cara yang berbeda yaitu melalui intravena infus (iv infus) dan intravena bolus (iv bolus), dan efek dari kedua jenis pemberian tersebut belum diketahui. Tujuan dari penelitian ini adalah membandingkan efek protokol manajemen hipoglikemia dengan larutan pekat D40\% secara iv infus dan iv bolus terhadap respon gula darah pascakoreksi di dua rumah sakit dengan protokol yang berbeda. Penelitian analitik komparatif secara potong lintang ini dilakukan secara retrospektif di RS St. Carolus (kelompok iv infus D40\%) dan RS Bella (kelompok iv bolus D40\%). Respon gula darah, dalam bentuk koefisien variasi dan derajat overkoreksi, dibandingkan antara kedua kelompok. Median kenaikan gula darah pada kelompok iv infus $\mathrm{D} 40 \%$ 69,5 (3-195) $\mathrm{mg} / \mathrm{dL}$ ( $\mathrm{n}=60$ pasien) dan kelompok iv bolus $\mathrm{D} 40 \% 77(15-249) \mathrm{mg} / \mathrm{dL}$ ( $\mathrm{n}=62$ pasien) $(\mathrm{p}=0,259)$. Koefisien variasi dengan iv infus adalah $47,18 \%$ dan iv bolus $52,75 \%$. Median derajat overkoreksi iv infus D40\% lebih rendah dibandingkan iv bolus D40\%, dengan masing-masing 10\% $(0-138 \%)$ dan 23\% (0-195\%). Kedua cara pemberian D40\% tidak memiliki hubungan yang bermakna dengan derajat overkoreksi (uji Mann-Whitney; $\mathrm{p}=0,099$ ). Pemberian iv infus dan bolus $\mathrm{D} 40 \%$ tidak memiliki pengaruh terhadap respon gula darah pascakoreksi.
\end{abstract}

Kata kunci: Dekstrosa 40\%, gula darah, hipoglikemia, intravena bolus, intravena infus

Correspondence: Yuriani, M.Farm., Apt., Faculty of Pharmacy, University of Indonesia, Depok, Jawa Barat 16424, Indonesia, email: yurianijoe@yahoo.com

Submitted: $8^{\text {th }}$ May 2019, Accepted: 24 ${ }^{\text {th }}$ June 2019, Published: $28^{\text {th }}$ June 2019 


\section{Introduction}

Both glucose spikes ${ }^{1,2}$ and blood glucose fluctuation $^{3-5}$ have been proven through a series of studies to be capable of increasing oxidative stress and more dangerous than the conditions of persistent hyperglycaemia. It is therefore necessary for finding hypoglycaemia treatment protocol that is not only to ensure hypoglycaemia resolution, but also to avoid excessive post-correction blood sugar response. Hypoglycaemia treatment protocol endorsed by The Indonesian Society for Endocrinology (Perkumpulan Endokrinologi Indonesia or PERKENI) was to give $20 \%$ dextrose (D) as much as $50 \mathrm{~mL}$ (if forced, $\mathrm{D} 40 \%$ can be given as much as $25 \mathrm{~mL}$ ), followed by D5\% or D10\% infusion. ${ }^{6}$ In fact, there are two different ways found in giving D40\%, as the only dextrose concentrated solution available in Indonesia, to hypoglycaemic patients, through intravenous (iv) infusion and bolus. The recommendation differs from the latest guideline by Joint British Diabetes Societies, that is to give $75-100 \mathrm{~mL}$ of D20\% for 15 minutes. ${ }^{7}$

The search of previous literature showed various potential strategies in optimizing the management of hypoglycemia. Experimental research by Moore et al. compared the use of $10 \%$ and $50 \%$ dextrose solution for treatment of hypoglycemia in pre-hospital setting. There was no difference in time to reach full awareness with the two types of solution. ${ }^{8} \mathrm{~A}$ subsequent research conducted by Kiefer et al. (2014) proved that the use of D10\% in the management of hypoglycemia had little or no short-term decay in subsequent blood glucose values. ${ }^{9}$ As it has been known that the speed of giving dextrose solution also needs to pay attention to the body's ability to carry out the oxidation process, ${ }^{10}$ we could then hypothesize that by giving D $40 \%$ at a slower rate, that is through iv infusion, there would be less glucose spike while still achieving the resolution of hypoglycaemia. This study aims to compare the effect of a hypoglycemia treatment protocol using D40\% concentrated solution to the post-correction blood sugar response through iv infusion and bolus at two different hospitals with two distinct protocols in Indonesia.

\section{Methods}

This was a comparative cross-sectional study conducted at St. Carolus Hospital (D40\% iv infusion group) and Bella Hospital (D40\% iv bolus group). This study had been ethically approved by Research Ethic Committee from Faculty of Medicine Universitas Indonesia (10343/UN2.F1/ ETIK/2018).

Adult patients were included if they were admitted to the emergency department (ED) or inpatient wards with hypoglycemia receiving D40\%. For iv infusion group, D40\% must be diluted with $\mathrm{NaCl} 0.9 \%$ to ensure the same amount of dextrose given between groups. Dilution with $\mathrm{NaCl} 0.9 \%$ resulted in less concentrated dextrose solution. Hence, it was acknowledged that the solution was no longer $40 \%$ in concentration, but the total amount of dextrose given, 20 grams, was still the same between the compared groups. Patients were excluded if admitted for diabetic ketoacidosis, hyperosmolar hyperglycemic state, currently in pregnancy, and suffered from refractory hypoglycemia. A review of the electronic medical record was done between January 2016 and December 2018 for iv infusion group and between January 2014 and December 2018 for iv bolus group. Patient information collected included age, sex, use of D10\% after initiation of D $40 \%$, time to recheck blood glucose, use of insulin, insulin secretagogue, other oral antidiabetic drugs (OAD), chronic kidney disease (CKD), liver disease, and status of recurrent hypoglycaemia, and were assessed as confounders. CKD was defined as creatinine $>2 \mathrm{mg} / \mathrm{dL}$ within 24 hours up to the time of the event or requiring ongoing 
dialysis or diagnosis of with CKD stage III, $\mathrm{IV}$, or $\mathrm{V}$ on the medical record. Liver disease was defined as diagnosis of cirrhosis or acute fulminant hepatitis on the medical record.

The primary outcome was blood glucose response, in form of coefficient of variation and degree of overcorrection. The coefficient of variability defined as standard deviation/ mean blood glucose and the degree of overcorrection defined as (first blood glucose value after treatment- $100 \mathrm{mg} / \mathrm{dL}$ )/100. Using a conservative estimate of the confidence interval, we chose to target 120 patients (60 patients per group) to provide us with a $95 \%$ confidence level and confidence interval of $\pm 5 \%$. For statistical analysis, data that did not have parametric distribution were analyzed using a Chi-Square test, Fisher's exact test, or Mann-Whitney U test as indicated. Confounding variables were analyzed via multivariate logistic regression. All statistical analysis was conducted via IBM SPSS.

\section{Results}

A total of 70 patients who received iv infusion D $40 \%$ and 74 patients who received iv bolus D $40 \%$ were eligible for the study inclusion (Figure 1). Further matching of variable of time to recheck blood glucose $\left(1^{\text {st. }} ; 1.5^{\text {th. }} ; 2^{\text {nd }}\right.$ hour $)$ was done on both groups. The management of hypoglycaemia using D $40 \%$ concentrated solution varied between subject in this study. The use of D40\% varied from 10, 20, 30, and 40 grams of dextrose. This study used 20 grams of $\mathrm{D} 40 \%$ data as the majority data to be processed statistically. It was notable that for the iv infusion group, the concentration of dextrose given was no longer $40 \%$ due to dilution with $0.9 \%$ normal saline. The term D40\% iv infusion was still used to depict the same amount of dextrose given between compared groups, that was 20 grams of dextrose.

As a result, 122 patients were included for final analysis. Baseline patient characteristics

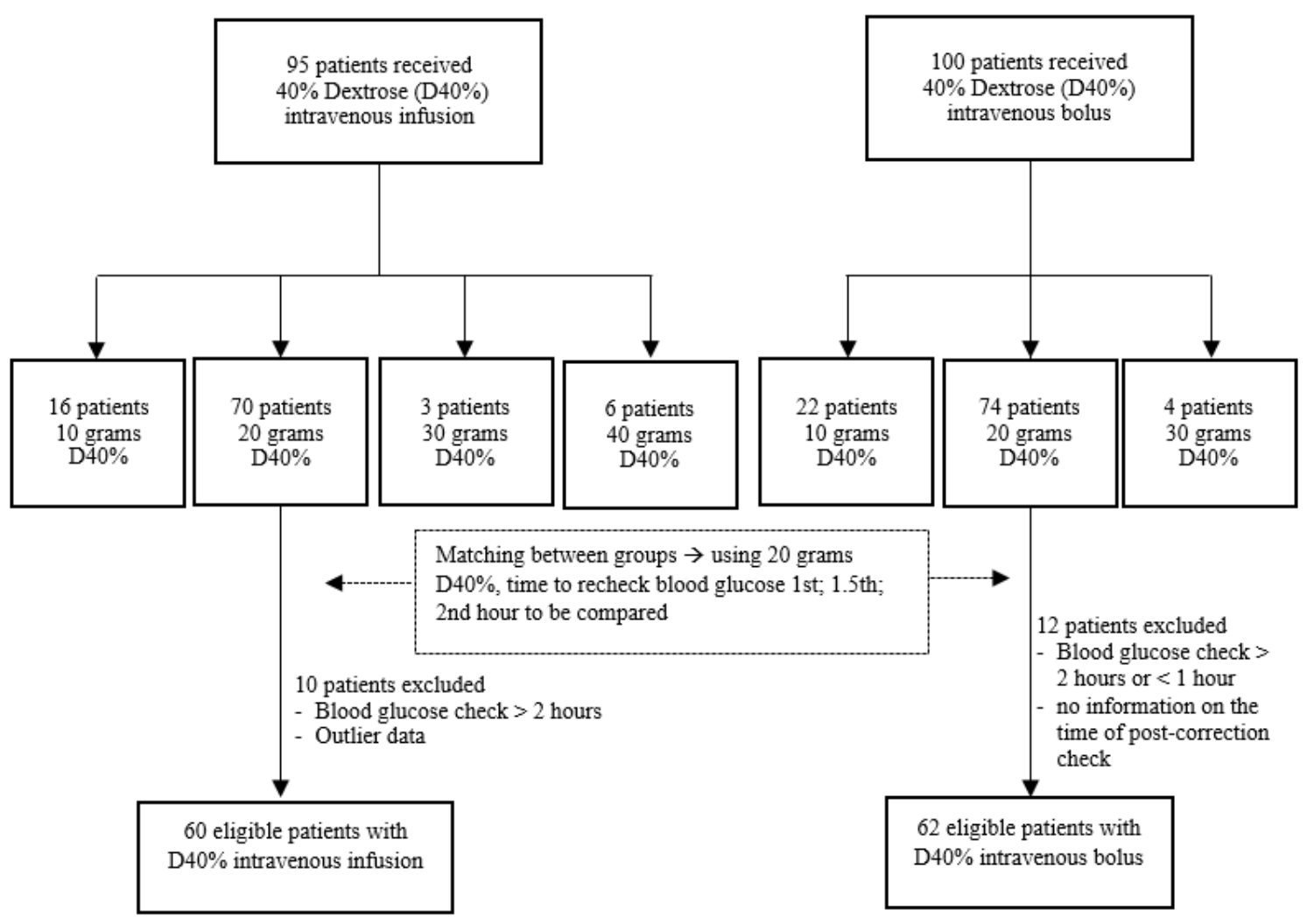

Figure 1 Patient Selection 
Table 1 Patient Characteristics

\begin{tabular}{|c|c|c|c|c|}
\hline Characteristics & Category & $\begin{array}{c}\mathrm{D} 40 \% \\
\text { Intravenous } \\
\text { Infusion }(\mathrm{n}=60)\end{array}$ & $\begin{array}{c}\text { D40\% } \\
\text { Intravenous } \\
\text { Bolus }(n=62)\end{array}$ & p-value \\
\hline \multirow[t]{2}{*}{ Age } & Adult $(18-<60$ years $)$ & 13 & 25 & 0.026 \\
\hline & Geriatric ( $>60$ years) & 47 & 37 & \\
\hline \multirow[t]{2}{*}{ Sex } & Male & 30 & 26 & 0.468 \\
\hline & Female & 30 & 36 & \\
\hline \multirow[t]{2}{*}{ D10\% Infusion } & Not using D $10 \%$ infusion & 45 & 17 & $<0.001$ \\
\hline & Using D10\% infusion & 15 & 45 & \\
\hline \multirow[t]{3}{*}{ Time to Recheck } & 2 hours & 21 & 16 & 0.453 \\
\hline & 1.5 hours & 8 & 12 & \\
\hline & 1 hour & 31 & 34 & \\
\hline \multirow[t]{2}{*}{ Insulin } & Not using insulin & 40 & 51 & 0.048 \\
\hline & Using insulin & 20 & 11 & \\
\hline \multirow[t]{2}{*}{ Insulin Secretagogue } & Not using insulin secretagogue & 31 & 24 & 0.203 \\
\hline & Using insulin secretagogue & 29 & 38 & \\
\hline \multirow[t]{2}{*}{ Oral Antidiabetics (OAD) } & Not using OAD & 41 & 29 & 0.018 \\
\hline & Using OAD & 19 & 33 & \\
\hline \multirow[t]{2}{*}{ Diabetes Mellitus (DM) Status } & No DM & 6 & 4 & 0.475 \\
\hline & $\mathrm{DM}$ & 54 & 58 & \\
\hline \multirow[t]{2}{*}{ Chronic Kidney Disease (CKD) } & No CKD & 23 & 34 & 0.073 \\
\hline & CKD & 37 & 28 & \\
\hline \multirow[t]{2}{*}{ Liver Disease } & No liver disease & 56 & 60 & 0.38 \\
\hline & Liver disease & 4 & 2 & \\
\hline \multirow[t]{2}{*}{ Recurrent Hypoglycemia } & No recurrent hypoglycemia & 49 & 47 & 0.429 \\
\hline & Recurrent hypoglycemia & 11 & 15 & \\
\hline
\end{tabular}

Note: $\mathrm{n}=$ number of patients; Diabetes mellitus (DM) status=type $2 \mathrm{DM}$; Chronic kidney disease (CKD) $=$ creatinine $>2 \mathrm{mg} / \mathrm{dL}$ within 24 hours up to the time of the event or requiring ongoing dialysis or diagnosis of with CKD stage III, IV, or V; Liver disease $=$ cirrhosis or acute fulminant hepatitis; Recurrent hypoglycemia=history of hypoglycaemia prior to the event

were presented on Table 1. The majority of patient in both groups were diabetics (54 patients iv infusion vs 58 patients iv bolus, $90 \%$ vs 93.5\%). All those diabetics were type 2 DM since no type $1 \mathrm{DM}$ was found in this study. Length of iv infusion in this study was 15 minutes, as it was the protocol of using D40\% in St. Carolus Hospital.

The majority of patient in this study were given D10\% infusion following D40\%. Patients with D10\% were given before D40\% were excluded. Iv D40\% infusion at St. Hospital Carolus was not given at the same time with D10\%. It was written in the medical record that D10\% infusion was installed after the D40\% infusion was used up. The infusion drip of $\mathrm{D} 10 \%$ in each patient in both hospitals varied, consisting of D10\% per 8 hours and per 12 hours, with the decision to terminate infusion depending on blood sugar testing in the following hours. The glucometer used by each hospital is different, with Terumo ${ }^{\circledR}$ at St. Carolus Hospital and Accucheck ${ }^{\circledR}$ at Bella Hospital.

The endpoint comparisons were presented in Table 2. The difference or increase in blood sugar before and after correction was expressed as change in blood glucose (change in BG). 
Table 2 Endpoint Comparison

\begin{tabular}{|c|c|c|c|}
\hline & $\begin{array}{l}\text { D40\% Intravenous Infusion } \\
(n=60)\end{array}$ & $\begin{array}{l}\text { D40\% Intravenous Bolus } \\
(n=62)\end{array}$ & p-value \\
\hline $\begin{array}{l}\text { Change in Blood Glucose } \\
{[\text { median (min-max)] }}\end{array}$ & $69.5(3-195)$ & $77(15-249)$ & $0.259^{\mathrm{a}}$ \\
\hline Coefficient of Variation & $47.18 \%$ & $52.75 \%$ & \\
\hline $\begin{array}{l}\text { Degree of Overcorrection } \\
{[\text { median }(\min -\max )]}\end{array}$ & $10 \%(0-138 \%)$ & $23 \%(0-195 \%)$ & $0.099^{\mathrm{a}}$ \\
\hline
\end{tabular}

The overall median of change in BG was $69.5(3-195) \mathrm{mg} / \mathrm{dL}$ for iv infusion group $(\mathrm{n}=60)$ and $77(15-249) \mathrm{mg} / \mathrm{dL}$ for iv bolus group $(n=62)(p=0.259)$. The change in BG also became the basis for calculating the coefficient of variation. The coefficient of variation with iv infusion and iv bolus group were $47.18 \%$ and $52.75 \%$, respectively. The degree of overcorrection was calculated if post-correction blood glucose exceeded $100 \mathrm{mg} / \mathrm{dL}$. If the patient's post-correction blood sugar did not exceed $100 \mathrm{mg} / \mathrm{dL}$, then the degree of overcorrection was expressed as a value of 0 . The median of degree of overcorrection in iv infusion group was lower compared with iv bolus group, 10\% (0-138\%) versus $23 \%(0-195 \%)$, respectively. The degree overcorrection in these patients was also defined categorically and then analysed the proportion and relationship between the way of administering D40\% and overcorrection of blood sugar by Chi-Square test. This analysis was as shown in the Table 3. The proportion of the prevalence of blood sugar overcorrection in the iv bolus group was $45 / 62(72.6 \%)$ vs iv infusion group was $38 / 60(63.3 \%)$. The risk of patients in the iv bolus group to experience blood sugar overcorrection was higher compared to the iv infusion group, with prevalence ratio (PR) of 1.15 and $95 \%$ CI $0.896-1.465$. Statistically by Chi-square test, the incidence of blood sugar overcorrection between groups did not differ significantly, with a $p$-value $=0.274$.

\section{Discussion}

To the best of our knowledge, this is the first study which compares the effect on D40\% administration, intravenous infusion and bolus, to blood sugar response in hypoglycaemic patients. The time to recheck blood sugar in this study was not the same as the recommendation of PERKENI, which was 15 minutes after correction. ${ }^{6}$ Time to recheck blood glucose in this study was carried out varied at the $1^{\text {st }}$ hour, $1.5^{\text {th }}$ hour and $2^{\text {nd }}$ hour. The retrospective study by Bilhimeret et al. at University of Rochester Teaching Hospital provided an overview of the management of hypoglycemia in the ED. ${ }^{11}$ The median time for blood sugar examination after intravenous bolus administration of $50 \%$ dextrose solution was 22 (IQR 8-44) minutes. The time of rechecking might also depend on

Table 3 Proportion of Overcorrection Events

\begin{tabular}{lcccc}
\hline \multicolumn{1}{c}{ Variable } & $\begin{array}{c}\text { D40\% Intravenous Bolus } \\
\text { (n) }\end{array}$ & $\begin{array}{c}\text { D40\% Intravenous Infusion } \\
\text { (n) }\end{array}$ & PR (CI 95\%) & p-value \\
\hline Overcorrection & 45 & 38 & 1.15 & $0.274^{\mathrm{a}}$ \\
Without overcorrection & 17 & 22 & $(0.896-1.465)$ & \\
\hline Note: $\mathrm{n}=$ number of patients; a=Chi-Square test; PR=prevalence ratio; CI=confidence interval & &
\end{tabular}


the bustle of the staff. Therefore, it could be understood that difference in rechecking time would occur anywhere else.

Previous study examining serum glucose changes after administration of D50\% in diabetic patients admitted to ED varied from 37 to $379 \mathrm{mg} / \mathrm{dL} .{ }^{12}$ The median change in BG in this study was $69.5 \mathrm{mg} / \mathrm{dL}$ and $77 \mathrm{mg} /$ $\mathrm{dL}$ the iv infusion group and iv bolus group, respectively. Dextrose infusion rate needs to consider the rate of glucose oxidation. Dextrose's oxidation can be reduced in patients with hypermetabolic conditions, patients with diabetes, elderly patients, and interaction with concurrent medications..$^{13}$ Most of the studied patient population was diabetics, yet we did not find any difference regarding their blood sugar response compared to non-diabetics. No difference was also found between elderly in comparison with adult patient population. Result of this comparative study was unable to explain the correlation between D40\% rate of administration to blood sugar response. We could only state that the variability of glucose rise was less in iv infusion group, while change in BG was not statistically different between groups.

This study tried to find better protocols to reduce blood sugar spike. The term degree of overcorrection, with a threshold of $100 \mathrm{mg} /$ $\mathrm{dL}$, was used to describe an increase in postcorrection blood glucose regardless of the initial blood sugar value at the time of hypoglycaemia. The limit of $100 \mathrm{mg} / \mathrm{dL}$ was based on previous study by Murthy et al. ${ }^{14}$ The study provided an overview of the blood glucose response by administering D50\% in critically ill patients receiving insulin infusion. A total of $49 \%$ of patients experiencing an increase in blood glucose above $100 \mathrm{mg} / \mathrm{dL}$ post-correction indicated a high glycemic variability. The smaller the degree of overcorrection in the iv infusion or bolus D40\%, the smaller the blood sugar spike that occured. Patient factors such as age, sex, use of D10\% after initiation of
D40\%, time to recheck blood glucose, use of insulin, insulin secretagogue, other OAD, CKD, liver disease, and status of recurrent hypoglycaemia were found to have minimal impact to blood sugar response. This finding was in an agreement with previous study by Arnold et al. ${ }^{15}$

Non-significant differences in post-correction blood sugar response from administration of D40\% iv bolus and infusion in this study can be caused by the small number of samples. The preference for using D $40 \%$ concentrated solution for the management of hypoglycaemia at this time is by iv infusion for 15 minutes until proven through further research. The use of iv infusion by diluting $\mathrm{D} 40 \%$ in $\mathrm{NaCl} 0.9 \%$ also decreases the osmolarity of the infusion, providing safer method for peripheral vein administration. The latter was the reason for the studied hospital to use different protocol as it was recommended by PERKENI.

Our study has noted limitations. We did not quantify the amount of D10\% received after D $40 \%$ administration. This might lead to unforeseen variability in subsequent serum glucose levels. The glucometer used between groups were also different, that might affect the blood glucose readings. However, both hospitals provided the evidence of routine calibration of the glucometers to ensure the validity of the blood glucose readings. Due to retrospective nature of this study, we were unable to relate the pharmacokinetics profile from insulin, insulin secretagogue, and OAD to blood sugar response, as the data of last time the patient took the medicine were unavailable. Other concurrent medications used by subjects of this study were not also considered.

\section{Conclusions}

D40\% iv infusion and bolus administration had no effect to the post-correction blood sugar response. Further prospective study may 
address any bias issues in this study.

\section{Funding}

This research received no specific grant from any funding agency in the public, commercial, or not-for-profit sectors.

\section{Conflict of Interest}

The authors declared no potential conflicts of interest with respect to the research, authorship, and/or publication of this article

\section{References}

1. Ceriello A, Novials A, Ortega E, La Sala L, Pujadas G, Testa R, et al. Hyperglycemia following recovery from hypoglycemia worsens endothelial damage and thrombosis activation in type 1 diabetes and in healthy controls. Nutr Metab Cardiovasc Dis. 2014; 24(2):116-23. doi: 10.1016/j.numecd.2013 .05 .003

2. Ceriello A, Novials A, Ortega E, La Sala L, Pujadas G, Testa R, et al. Evidence that hyperglycemia after recovery from hypoglycemia worsens endothelial function and increases oxidative stress and inflammation in healthy control subjects and subjects with type 1 diabetes. Diabetes. 2012;61(11):2993-7. doi: 10.2337/db12-0 224.

3. Eslami S, Taherzadeh Z, Schultz MJ, AbuHanna A. Glucose variability measures and their effect on mortality: A Systematic Review. Intensive Care Med. 2011;37(4): 583-93. doi: 10.1007/s00134-010-21 295.

4. Hermanides J, Vriesendorp TM, Bosman RJ, Zandstra DF, Hoekstra JB, Devries $\mathrm{JH}$. Glucose variability is associated with intensive care unit mortality. Crit Care Med. 2010;38(3):838-42. doi: 10.1097/C CM.0b013e3181cc4be9.
5. Ceriello A, Ihnat MA. 'Glycaemic variability': A new therapeutic challenge in diabetes and the critical care setting. Diabet Med. 2010;27(8):862-7. doi: 10.1 111/j.1464-5491.2010.02967.x.

6. Pengurus Besar Perkumpulan Endokrinologi Indonesia. Konsensus pengendalian dan pencegahan diabetes melitus tipe 2 di Indonesia 2015. Jakarta: PB PERKENI; 2015.

7. Joint British Diabetes Societies. The hospital management of hypoglycaemia in adults with diabetes mellitus. Joint British Diabetes Societies for Inpatient Care, 2018 [Acsessed on: 24 July 2018]. Available at: http://diabetestimes.co.uk/ wp-content/uploads/2018/05/JBDS_Hypo Guideline.pdf-FINAL-08.03.18.pdf

8. Moore C, Woollard M. Dextrose $10 \%$ or $50 \%$ in the treatment of hypoglycaemia out of hospital? A randomised controlled trial. Emerg Med J. 2005;22(7):512-5. doi: 10.1136/emj.2004.020693

9. Kiefer MV, Hern G, Alter HJ, Barger JB. Dextrose $10 \%$ in the treatment of out-ofhospital hypoglycemia. Prehosp Disaster Med. 2014;29(2):190-4. doi: 10.1017/S1 $049023 X 14000284$.

10. American Society for Parenteral and Enteral Nutrition. Safe practices for parenteral nutrition. J Parenter Enter Nutr 2004;28(6):S39-70. doi: 10.1177/014860 $7104028006 \mathrm{~S} 39$

11. Bilhimer $\mathrm{MH}$, Treu CN, Acquisto NM. Current practice of hypoglycemia management in the ED. Am J Emerg Med 2017;35(1):87-91. doi: 10.1016/j.ajem.2 016.10.009

12. Adler PM. Serum glucose changes after administration of $50 \%$ dextrose Solution: Pre- and in-hospital calculations. Am J Emerg Med. 1986;4(6):504-6. doi: 10.10 16/S0735-6757(86)80004-3

13. Btaiche IF, Khalidi N. Metabolic complications of parenteral nutrition in 
adults, part 1. Am J Heal Syst Pharm 2004; 61(18):1938-49. doi: 10.1093/ajhp/61.18. 1938

14. Murthy MS, Duby JJ, Parker PL, Durbin-Johnson BP, Roach DM, Louie EL. Blood glucose response to rescue dextrose in hypoglycemic, critically Ill patients receiving an insulin infusion. Ann
Pharmacother. 2015;49(8):892-6. doi: 10. $1177 / 1060028015585574$.

15. Arnold P, Paxton RA, McNorton K, Szpunar S, Edwin SB. The effect of a hypoglycemia treatment protocol on glycemic variability in critically ill patients. J Intensive Care Med. 2015;30(3):156-60. doi: 10.1177/0885066613511048. 